\title{
Assessment of Rusty Blackbird Habitat Occupancy in the Long Range Mountains of Newfoundland, Canada Using Forest Inventory Data
}

\author{
Kathleen K. E. Manson ${ }^{1}$, Jenna P. B. McDermott ${ }^{2}$, Luke L. Powell ${ }^{3,4,5, *(\mathbb{D} \text {, Darroch M. Whitaker }}{ }^{6}$ \\ and Ian G. Warkentin 1,2,7 \\ 1 School of Environmental Sciences, University of Guelph, Guelph, ON N1G 2W1, Canada; \\ kathleenmanson1@gmail.com (K.K.E.M.); ian.warkentin@grenfell.mun.ca (I.G.W.) \\ 2 Cognitive and Behavioural Ecology Program, Memorial University of Newfoundland, \\ St. John's, NL A1B 3X7, Canada; jmcdermott@mun.ca \\ 3 Institute of Animal Health and Comparative Medicine, University of Glasgow, Glasgow G12 8QQ, UK \\ 4 Department of Biosciences, Durham University, Stockton Road, Durham DH13LE, UK \\ 5 Biodiversity Initiative, Houghton, MI 49931, USA \\ 6 Parks Canada, Rocky Harbour, NL A0K 4N0, Canada; darroch.whitaker@canada.ca \\ 7 Environmental Science, Memorial University of Newfoundland, Corner Brook, NL A2H 6P9, Canada \\ * Correspondence: Luke.L.Powell@gmail.com
}

Received: 13 May 2020; Accepted: 29 August 2020; Published: 4 September 2020

\begin{abstract}
Rusty blackbirds (Euphagus carolinus), once common across their boreal breeding distribution, have undergone steep, range-wide population declines. Newfoundland is home to what has been described as one of just two known subspecies (E. c. nigrans) and hosts some of the highest known densities of the species across its extensive breeding range. To contribute to a growing body of literature examining rusty blackbird breeding ecology, we studied habitat occupancy in Western Newfoundland. We conducted 1960 point counts across a systematic survey grid during the 2016 and 2017 breeding seasons, and modeled blackbird occupancy using forest resource inventory data. We also assessed the relationship between the presence of introduced red squirrels (Tamiasciurus hudsonicus), an avian nest predator, and blackbird occupancy. We evaluated 31 a priori models of blackbird probability of occurrence. Consistent with existing literature, the best predictors of blackbird occupancy were lakes and ponds, streams, rivers, and bogs. Red squirrels did not appear to have a strong influence on blackbird habitat occupancy. We are among the first to model rusty blackbird habitat occupancy using remotely-sensed landcover data; given the widespread availability of forest resource inventory data, this approach may be useful in conservation efforts for this and other rare but widespread boreal species. Given that Newfoundland may be a geographic stronghold for rusty blackbirds, future research should focus on this distinct population.
\end{abstract}

Keywords: red squirrel; boreal; wetland; Euphagus carolinus; point count; remotely sensed landscape data; unmarked

\section{Introduction}

Though the rate of decline may have eased in the last decade [1], long-term monitoring has documented range-wide declines in rusty blackbird (Euphagus carolinus) populations that exceed 80\% over the past century, with qualitative evidence for declines dating back to the 19th century [2-4]. Migratory species such as blackbirds can be affected by stressors or threats acting during any or all phases of the annual cycle [5,6]. The factors driving this dramatic range-wide decline in the formerly wide-spread and common rusty blackbird are not fully understood, though this species may have 
been affected by threats manifested during at least two phases of the annual cycle. Multiple stressors on the species' wintering grounds have likely contributed to declines, including: "Pest" control measures on agricultural land that target other species of blackbirds but also lead to incidental rusty blackbird mortality [7]; loss of up to $80 \%$ of potential wintering wetland habitat through conversion to agricultural land use and fragmentation [3]; and exposure to high levels of methyl mercury through dietary intake (during both wintering and breeding) that could cause physiological or reproductive impacts [8]. Factors acting on the species' boreal forest breeding grounds have also likely contributed to population declines [2], including wetland conversion for agricultural purposes $[9,10]$ and habitat degradation linked to climate change [11,12]. Regarding the latter, McClure et al. [11] detected a 143 $\mathrm{km}$ northward shift in the southern edge of the breeding range of rusty blackbirds between 1966 and 2005, and also found a significant correlation between rusty blackbird population declines detected in Breeding Bird Survey (BBS) data and Pacific Decadal Oscillations. McClure et al. [11] suggested that warmer temperatures and drier conditions may reduce the amount of arthropod prey and change prey phenology, resulting in a temporal disconnect between breeding phenology and prey availability.

Habitat and habitat quality can play key roles in determining both distribution and productivity of forest songbirds $[13,14]$ and boreal songbirds are known to be influenced by factors that include natural $[15,16]$ and anthropogenic disturbance $[17,18]$. Broad-scale breeding season habitat associations have been described for rusty blackbirds [4] and various factors have been hypothesized as influencing them on their breeding grounds. These factors include competition with other icterids [19], timber harvesting [20,21], changes to wetland hydrology and ecology [11], and nest predator dynamics [22]. However, though most jurisdictions across the boreal biome maintain relatively standardized forest resource inventory landcover databases to support the management of forests and other natural resources, few studies have quantitatively assessed breeding habitat for rusty blackbirds using forest inventory data. Given their widespread availability and direct role in natural resource management planning, forest inventory data may be particularly useful for efficient, cost-effective monitoring, and for studying a widespread and rare species such as the Rusty Blackbird. This is especially true in the boreal forest, which is often remote or inaccessible to surveyors. Further, these landcover inventories may be used to identify key habitat for conservation and management of species across a wide geographic area, and so may prove useful when applied in the conservation of boreal species at risk.

The breeding range of rusty blackbirds extends across the boreal forest of Canada and the United States, and within this biome breeding activity is most often associated with wetland and riparian ecosystems and adjacent dense conifer stands [4]. During the breeding period, rusty blackbirds forage primarily on aquatic invertebrates along the shorelines of lakes and streams but occasionally seek terrestrial prey [22,23]. Powell et al. [24] assessed breeding site occupancy of rusty blackbirds using ground-based measurement of habitat features (i.e., they did not use remotely sensed data); occupancy was affected by various factors acting at multiple spatial scales, but was driven primarily by the availability of wetlands that afforded suitable foraging opportunities (i.e., areas of shallow water) and evidence of beaver (Castor canadensis) activity. The presence of dense patches of conifers in the vicinity of those wetlands was also required for nesting, while stand age and harvest history were less influential [24]. Lack of specificity in the latter matches the largely anecdotal descriptors of nest substrates reported elsewhere; rusty blackbirds appear to prefer nesting in short (less than $4.5 \mathrm{~m}$ tall), dense conifer stands [21,22,25-27], and predominantly use black spruce (Picea mariana) and balsam fir (Abies balsamea) near wetlands [24]. They have also been reported nesting in willow thickets (Salix sp.; [23]). Most recently, Wohner et al. [27] assessed rusty blackbird habitat use during various periods of the breeding season. They found that streams, softwood and mixed wood sapling stands, wetlands, and areas characterized by slopes between $1 \%$ and $8 \%$ were important in predicting rusty blackbird occupancy. Streams were very important in predicting nest sites and adult occupancy, but were especially important in predicting fledgling occupancy. In contrast, fledglings and adults strongly selected wetlands, but this habitat was not strongly associated with nest sites. Wohner et al. [27] 
proposed that streams may be a more important source of smaller arthropod prey for nestlings, whereas wetlands may host larger prey-for example, dragonflies-valuable for adults and large dependent fledglings.

There has been limited research on the impact of nest predators on rusty blackbirds. Matsuoka et al. [25] assessed nesting success in rusty blackbirds and found that of failed nests, $89 \%$ were lost to depredation, and various studies have shown that predation risk can affect nest site selection in songbirds (e.g., [28]). In a study of rusty blackbird nest success, Luepold et al. [22] found that North American red squirrels (Tamiasciurus hudsonicus) were the most frequent predator of rusty blackbird nests in Maine, USA. Red squirrels are an important predator of nests and fledglings of boreal songbirds that can affect populations and community structure (e.g., [29-31]). Red squirrels were introduced to Newfoundland, Canada during the 1960s and spread rapidly; they are now the most important predator of songbird nests on the island [32-34]. Squirrels have been implicated in the imperilment of two endemic Newfoundland songbird subspecies and represent a novel threat that may affect rusty blackbird nesting success, habitat associations, and abundance on Newfoundland [35,36]. During concurrent research at our study site, McDermott et al. [37] determined that during the 2016 summer season that followed a high mast crop (G. Robineau-Charette and D. Whitaker, unpublished data), red squirrels were detected at $18 \%$ of survey points. In contrast, during the 2017 summer season which followed a low mast crop, detections occurred at only $5 \%$ of survey points. During both years there was a negative relationship between squirrel detections and elevation with no squirrels detected above $515 \mathrm{~m}$ in either year (see [37] for further details). Benkman [38] suggested that red squirrel populations on Newfoundland were more than double those of mainland North American populations.

Forest management has been shown to affect breeding distribution, behavior and success in many species of birds (e.g., [39-41]). By contrast, Powell et al. [24] found that recent logging in adjacent uplands did not feature among the variables retained in the best occupancy models for rusty blackbirds in Northern New England, USA. However, an assessment of nesting success in regenerating, recently harvested stands versus older, established stands at the southern edge of the rusty blackbird breeding range in Maine suggested that recently harvested areas are an ecological trap, with nests in older stands being 2.3 times more likely to fledge young than nests in stands $<20$ years post-harvest [20]. Conversely, Buckley [26] found that nesting success in managed forest stands was comparable to that for other cup-nesting species, while Wohner et al. [27] suggested that regenerating softwood forests provided dense cover for fledglings to hide from predators. More research is needed to examine the role of forest harvesting at territory and landscape scales on habitat occupancy by rusty blackbirds, and to assess the extent to which such findings from southern portions of the breeding range are applicable in more northerly boreal regions.

As has occurred in continental portions of the rusty blackbird breeding range, the population on the island of Newfoundland experienced a significant decline between 1970 and 2014, as estimated from Breeding Bird Survey (BBS) data ( $-6.33 \%$ per year, $95 \%$ credible interval -3.58 to -9.35 based on 23 routes; [1]). Despite this decline, the number of individuals encountered per BBS route on Newfoundland was substantially higher than for all other regions ([7]; mean of 2.03 birds per route on Newfoundland based on data from 1980-2005 compared to a survey-wide mean of 0.26 birds per route for data collected from 1966-2005). As is the case for many bird species found on the island of Newfoundland [42-44], it has been suggested that the rusty blackbird population breeding on Newfoundland and possibly some adjacent portions of Atlantic Canada may be a distinct subspecies (E. c. nigrans) from that found across the remainder of the boreal forest (E. c. carolinus; [45]), and so may represent a distinct conservation unit for rusty blackbirds. Thus, Newfoundland appears to remain a stronghold for rusty blackbirds and is an important element for range-wide conservation planning.

We used an occupancy modelling approach based on two years of systematic survey data from a $257 \mathrm{~km}^{2}$ study area in western Newfoundland to assess how rusty blackbird occupancy is influenced by habitat. We used forest resource inventory landcover data derived from aerial photography to measure habitat availability, an uncommon approach for rusty blackbirds (but, see Bale et al. [46], 
Wohner et al. [27], who used aerial photography-derived habitat data). In addition, we evaluated the influence of red squirrel presence on the probability of blackbird occupancy. We predicted that rusty blackbirds would be associated with wet environments-specifically, waterbodies, watercourses, and bogs-and coniferous stands. Furthermore, we predicted that rusty blackbird occupancy and red squirrel presence would be negatively related.

\section{Materials and Methods}

\subsection{Study Site}

We collected data in the Main River and upper Humber River watersheds, located on the eastern slope of the Long Range Mountains of western Newfoundland, Canada $\left(49.75^{\circ} \mathrm{N}, 57.25^{\circ} \mathrm{W}\right.$; Figure 1; see also [36,37]). The $257 \mathrm{~km}^{2}$ study area spans an elevation range from $75 \mathrm{~m}$ to $608 \mathrm{~m}$, with elevation increasing from southeast to northwest. Landcover is dominated by wet boreal forest [47] containing a mosaic of mixed and single-species stands dominated by balsam fir or black spruce along with white birch (Betula papyrifera), tamarack (Larix laricina), and white spruce (P. glauca). Much of the mature forest consists of a closed canopy with few, large canopy gaps, and trees at higher elevations tend to have more stunted growth forms [48]. $68 \%$ of sites had $>25 \%$ cover of forest stands older than approximately 30 years of age. In a study in the northern boreal forest of Alaska and Yukon Territory, Viglas et al. [49] found that 30 year old trees had an approximately $50 \%$ chance of producing cones, and that this probability increased with age. Thus, a large proportion of our survey area may provide valuable habitat for red squirrels. Qualitative evidence suggests there was a large cone crop in 2015-2016, with a lighter cone crop during 2016-2017 (G. Robineau-Charette and D. Whitaker, unpublished data). Approximately $5 \%$ of our survey points were located above $550 \mathrm{~m}$, the approximate altitude of the tree line [48]. Various forms of boreal wetlands and aquatic habitat suitable for rusty blackbirds are widespread across the study area, including bogs, fens, and the shorelines of rivers and lakes, while barrens and other natural openings also make up a proportion of landcover. Overall, landcover within our survey point buffers consisted of an average of 3\% lakes, $7 \%$ bog, $29 \%$ coniferous scrub, and $48 \%$ balsam fir- and/or black spruce-dominated forest. Natural disturbances such as wildfire and outbreaks of defoliating insects are uncommon at higher elevations due to climatic conditions, leading to the development of mixed age, old growth fir forests having an abundance of canopy gaps and complex vertical structure [48,50]. Trees at this site have been aged at over 250 years old [48], and around our survey points alone, $27 \%$ of points contained $50 \%$ or more forest greater than 110 years old. Portions of the study area were harvested by clearcutting between 1990 and 2004 resulting in 19.7\% of the study area being cleared in cutblocks ranging from 0.30 ha to 197.4 ha; natural regeneration of balsam fir has followed harvest at these sites. The construction of a $60 \mathrm{~m}$-wide electricity transmission corridor during 2016 and 2017 (Figure 1) created a linear strip of cleared land through the study area. All lands in the study area are provincial public lands (i.e., "Crown lands").

\subsection{Field Methods}

We collected field data from early June through mid-July of 2016 and 2017 to span the period of peak territorial display and defense for most migratory songbirds in the region, including rusty blackbirds. Systematic surveys were carried out across a grid of points spaced $500 \mathrm{~m}$ apart (Figure 1), and for the 2017 season we shifted the grid $250 \mathrm{~m}$ north and $250 \mathrm{~m}$ east so that survey points fell midway between those sampled the previous year (i.e., a diagonal distance of $354 \mathrm{~m}$ from the points sampled the previous year). The total number of surveyed points was 991 during 2016 and 969 in 2017. Solitary observers conducted point counts; data collection included four surveyors during 2016 and five surveyors in 2017 (one individual was common to both seasons). Each surveyor sampled 5-12 adjacent points per day between $05: 40 \mathrm{~h}$ and 14:30 $\mathrm{h}$. This timeline deviated from standardized avian survey protocols such as Breeding Bird Surveys [51] and was devised as part of a survey using call broadcast originally designed to target gray-cheeked thrush (Catharus minimus) and red squirrels 
(see description below, and [37]). However, $85 \%$ of our point counts were conducted before 10am, and the probability of rusty blackbird detection did not vary substantially between hours within our survey period, despite a larger standard error after 13:00. Surveyors recorded wind strength using the Beaufort scale, and stopped field work when high winds ( $>5$ Beaufort scale; $29 \mathrm{~km} / \mathrm{h}$ ) or precipitation/fog impaired visual or auditory detections of songbirds (similar to BBS protocol; [51]). We continued to operate in the presence of light drizzle and fog, as these weather conditions are frequent in this climate, particularly in the morning, and we believe that this approach did not detract from our capacity to detect individuals during surveys. Precipitation was recorded as either absent, fog, drizzle, rain, or snow. Surveyors also recorded cloud cover on a scale from 1-5 ( $0=$ no clouds, $1<25 \%$ cloud cover, $2=26-50 \%, 3=51-75 \%, 4=76-99 \%, 5=100 \%$ ).

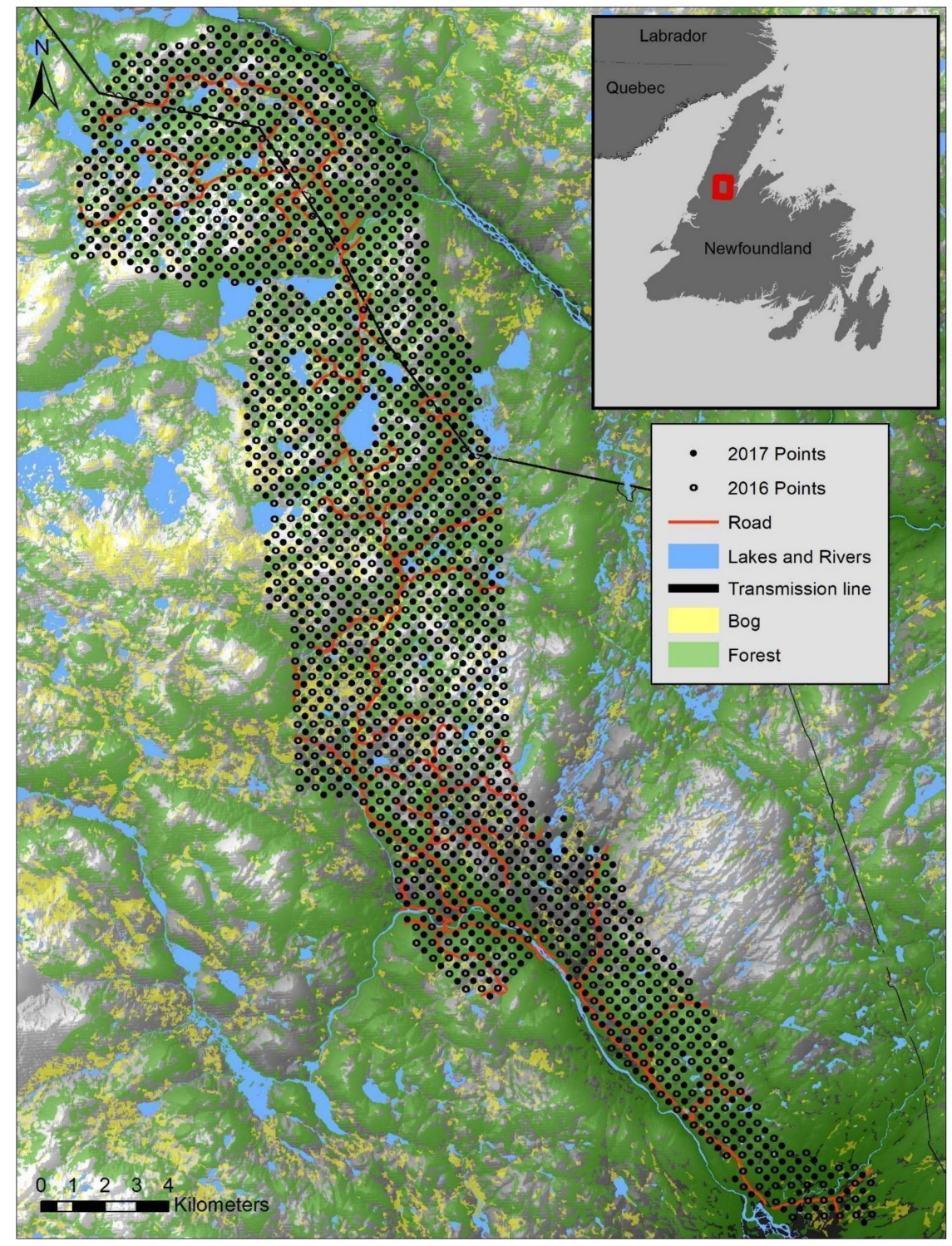

Figure 1. Distribution of survey points in the Main River and upper Humber River watersheds in western Newfoundland, Canada. Each year, points in the survey grid were spaced $500 \mathrm{~m}$ apart, and in 2017 the grid was shifted $250 \mathrm{~m}$ north and $250 \mathrm{~m}$ east, placing the points midway between those sampled the previous year. The location of the study area on the island of Newfoundland is shown by the red box on the inset map.

Surveyors visited each survey point once, conducting an 11-min unlimited radius point count [52] that was divided into the following sequence of five sub-periods: (1) six minutes silent listening; 
(2) two minutes broadcast of gray-cheeked thrush (Catharus minimus) calls and songs (3) a one-minute silent period; (4) one minute broadcast of red squirrel vocalizations; and (5) a final one-minute silent period. These subperiods were designed for an unrelated study that examined the relationship between gray-cheeked thrush and red squirrels. However, we recorded all bird species seen and/or heard and each red squirrel detected during each of the time blocks within the $11 \mathrm{~min}$ of a point count. As such, these methods provided suitable data for our study on rusty blackbirds. There is no reason to believe that the broadcast of gray-cheeked thrush vocalizations would influence Rusty Blackbird behavior or detectability. However, rusty blackbirds are known to mob potential predators (e.g., $[25,53])$ so might be attracted rather than deterred by the squirrel broadcasts. Surveyors used broadcast equipment (FoxPro model FX3 or Crossfire game callers; FoxPro Incorporated, Lewistown, PA 17044, USA) played at a consistent volume; when measured $1 \mathrm{~m}$ from the speaker, the peak volume of broadcasts was $82.6 \mathrm{~dB}$.

\subsection{Data Analysis}

Using ArcMap (version 10.5.1; [54]), we extracted landcover data for each survey point from the provincial forest resource inventory Geographic Information System (GIS) database, which was created using high resolution (sub $10 \mathrm{~cm}$ pixel resolution) 3D aerial photographs taken in 2007. Landcover was mapped according to the standard forest resource inventory classification scheme used by the Province of Newfoundland and Labrador, with landcover elements assigned to cover types (e.g., forest, forest scrub, bog, barren, lakes and ponds, rivers). Forest stands were further classified according to 20-year age classes and dominant tree species composition. The provincial forest resource inventory only includes rivers $>15 \mathrm{~m}$ wide, which are mapped as two-dimensional landcover features (i.e., polygons). However, smaller streams are likely important habitat features for rusty blackbirds [24,27], and are classified as linear features (i.e., 1-dimensional vectors) in Natural Resources Canada's CanVec geospatial database (available under the Government of Canada's open government License [https://open.canada.ca/en]). The national Canvec database is produced using several data sources and resolution varies from 1:10,000-1:50,000 scale. Consequently, we extracted two variables for moving water: (1) The extent of rivers $>15 \mathrm{~m}$ wide $\left(\mathrm{m}^{2}\right)$ from the provincial forest resource inventory, and (2) the linear length of smaller streams $(\mathrm{m})$ from the CanVec database.

We extracted landcover information within a $347 \mathrm{~m}$ radius around each point (i.e., a 37.8 ha circle); this approximates the rusty blackbird home range estimate of $37.5 \pm 12.6$ ha developed by Powell et al. [20] based on radiotracking 13 rusty blackbirds ( 6 males, 7 females) in Maine. We converted point count detections of rusty blackbirds into presence-absence data for each point and standardized most habitat features as the proportion of the 37.8 ha buffer circle covered by that habitat type. The only exception was for streams, which were measured as the total length $(\mathrm{m})$ of streams in the 37.8 ha circle, and then re-scaled from $0-1$ by dividing these values by the maximum observed stream length (2463.7 $\mathrm{m})$. We assessed these raw landscape variables for collinearity using Spearman's $\rho$, and did not detect correlations that warranted further consideration or screening of variables (correlation coefficients were less than 0.45 , which is below thresholds requiring additional consideration [55]). We aggregated balsam fir and black spruce stands into conifer stands since we believed that they would function similarly as rusty blackbird habitat [4]. Additionally, we excluded habitat features that were present in the landscape but that (1) occurred at less than $10 \%$ of the total survey points, or (2) were presumed to be unimportant for rusty blackbirds based on current understanding of the species' habitat needs. The latter habitat features included soil barrens, herbaceous soil barrens, rock barrens, sand, fens, residential land, rights-of-way, cleared land, and forests that were not dominated by either balsam fir or black spruce. Based on this approach our final analysis included seven landcover variables (Table 1).

We used the package UNMARKED [56] in Program R version 3.5.1 [57], using the function "occu" to assess relationships between rusty blackbird occurrence and the seven landcover variables (Table 1) plus year, elevation, and red squirrel presence. This program allowed us to model rusty blackbird detectability prior to running occupancy models. We explored the potential influence of 
six variables (cloud cover, observer, precipitation type, wind strength, time of day, and day of the year) on likelihood of detection (Table 2) in order to predict occupancy more effectively [58]. Each of the five sub-periods of each point count was considered a site visit, for a total of 5 repeated visits (see [56]). Observer and precipitation type were fit as categorical variables. For both detectability and occupancy modeling (the latter described below), we considered the model having the lowest AICc as the best-fit model and based our conclusions primarily on this model. We then fit 31 a priori occupancy models including the null and global models. We used the best-fit detectability model as the base (i.e., null) model for all occupancy models. We formulated these models following the approach of Powell et al. [24] based on information presented in existing rusty blackbird habitat studies $[4,24]$ along with anecdotal reports. Similar to Powell et al. [24], our models included habitats which reflect where one could reasonably expect to find rusty blackbirds. Candidate models included various combinations of landcover variables, including hypothesized interactions between some terms, and this resulted in models containing biologically relevant combinations of (1) nesting habitat, and (2) foraging habitat, and (3) models containing nesting and foraging habitat (Table 3). We also included elevation and red squirrel presence/absence in several of our candidate models. Rather than exploring the influence of geographic coordinates on rusty blackbird occupancy, we considered elevation to be a relevant substitute for assessing overall spatial variation in occupancy. We chose this approach because elevation increases with increased latitude, but east-west dimensions at the study site do not vary drastically. Models having a $\triangle \mathrm{AIC}$ less than or equal to two were considered to be competing models (i.e., not measurably better than one-another), and the subset of top-ranked models having a cumulative weight of $95 \%$ were taken as the best model set [59].

Table 1. Landcover variables used in modeling rusty blackbird occupancy in Newfoundland, Canada, 2016 and 2017. Variables were measured as either the linear amount of the feature (streams [m]) or the proportion of landcover within a $347 \mathrm{~m}$ radius of each survey point (all other variables).

\begin{tabular}{ll}
\hline Landcover Variable & Description \\
\hline Lakes and Ponds & Fresh water bodies $>0.15$ ha at high water mark \\
Streams & Combined length $(\mathrm{m})$ of all streams $<15 \mathrm{~m}$ wide \\
Rivers & Watercourses $>15 \mathrm{~m}$ wide measured at the high water mark \\
Bogs & Wetlands where sphagnum moss is the dominant cover type \\
Conifer & Forest stands where Black Spruce or Balsam Fir makes up $75 \%$ or more of the basal area \\
Coniferous Scrub & Low productivity stands having $<10 \%$ crown closure and $>50 \%$ conifer. \\
Cut $90-04$ & Clearcuts harvested between 1990 and 2004. \\
\hline
\end{tabular}

Table 2. Candidate models explaining detectability of rusty blackbirds in Newfoundland, Canada, in 2016 and 2017 ( $n=1960$ survey points).

\begin{tabular}{ccccc}
\hline Model & $\mathbf{\Delta A I C}_{\mathbf{c}}$ & $\mathbf{L L}$ & $\mathbf{w}_{\mathbf{i}}$ & $\mathbf{K}$ \\
\hline Observer & $0^{\mathrm{a}}$ & -1352.11 & 0.67 & 9 \\
Cloud & 3.11 & -1359.71 & 0.14 & 3 \\
Precipitation & 4.53 & -1357.40 & 0.07 & 6 \\
Null & 4.76 & -1361.53 & 0.06 & 3 \\
Wind & 6.76 & -1361.53 & 0.02 & 3 \\
Date & 6.83 & -1361.56 & 0.02 & 3 \\
Time & 9.10 & -1362.70 & 0.01 & 3 \\
Date + Time & 11.93 & -1363.11 & 0.00 & 4 \\
\hline \multicolumn{5}{c}{}
\end{tabular}

${ }^{\mathrm{a}} \mathrm{AIC}_{\mathrm{c}}$ of best model $=2722.31$. 
Table 3. Candidate models describing occupancy ( $\Psi$ ) of rusty blackbirds in Newfoundland, Canada, in 2016 and 2017 ( $n=1960$ survey points). Models in the 95\% confidence set of best models are highlighted in bold. All models include a term for the effect of observer on detectability.

\begin{tabular}{|c|c|c|c|c|}
\hline Model & $\triangle \mathrm{AICc}$ & LL & wi & $\mathbf{K}$ \\
\hline$\Psi$ Observer Lakes and Ponds + Bogs + Streams + Rivers & $0^{a}$ & -1288.20 & 0.60 & 13 \\
\hline$\Psi$ Observer Lakes and Ponds + Bogs + Streams + Conifer Scrub & 2.49 & -1289.44 & 0.17 & 13 \\
\hline$\Psi$ Observer Lakes and Ponds + Bogs + Streams + Conifer & 3.09 & -1289.74 & 0.13 & 13 \\
\hline$\Psi$ Observer Global & 3.74 & -1284.98 & 0.09 & 18 \\
\hline$\Psi$ Observer Lakes and Ponds + Bogs + Cut90-04 + Red Squirrel & 20.33 & -1298.36 & 0.00 & 13 \\
\hline$\Psi$ Observer Lakes and Ponds + Bogs + Cut90-04 & 21.04 & -1299.73 & 0.00 & 12 \\
\hline$\Psi$ Observer Lakes and Ponds + Bogs & 22.66 & -1301.55 & 0.00 & 11 \\
\hline$\Psi$ Observer Lakes and Ponds + Bogs + Red Squirrel $x$ Elevation & 23.02 & -1298.70 & 0.00 & 14 \\
\hline$\Psi$ Observer Lakes and Ponds x Bogs & 23.69 & -1301.05 & 0.00 & 12 \\
\hline$\Psi$ Observer $\sim$ Lakes and Ponds + Bogs + Conifer + Red Squirrel & 23.95 & -1300.18 & 0.00 & 13 \\
\hline$\Psi$ Observer Lakes and Ponds + Bogs + Conifer & 24.62 & -1301.52 & 0.00 & 12 \\
\hline$\Psi$ Observer $\sim$ Lakes and Ponds + Bogs + Rivers + Conifer & 24.63 & -1300.51 & 0.00 & 13 \\
\hline$\Psi$ Observer Lakes and Ponds + Bogs + Red Squirrel + Elevation & 24.63 & -1300.51 & 0.00 & 13 \\
\hline 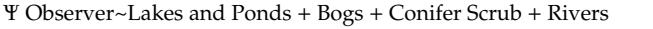 & 24.68 & -1300.54 & 0.00 & 13 \\
\hline$\Psi$ Observer Lakes and Ponds + Bogs + Conifer Scrub & 24.68 & -1301.55 & 0.00 & 12 \\
\hline$\Psi$ Observer Lakes and Ponds + Bogs + Conifer + Conifer Scrub & 26.63 & -1301.51 & 0.00 & 13 \\
\hline$\Psi$ Observer Lakes and Ponds + Conifer & 59.06 & -1319.75 & 0.00 & 11 \\
\hline$\Psi$ Observer Bogs + Streams + Conifer + Red Squirrel & 64.39 & -1320.39 & 0.00 & 13 \\
\hline$\Psi$ Observer Bogs + Streams + Conifer Scrub & 65.25 & -1321.84 & 0.00 & 12 \\
\hline$\Psi$ Observer Bogs + Streams + Conifer & 65.72 & -1322.07 & 0.00 & 12 \\
\hline$\Psi$ Observer Lakes and Ponds + Conifer Scrub & 68.91 & -1324.68 & 0.00 & 11 \\
\hline$\Psi$ Observer Streams + Conifer & 76.38 & -1328.41 & 0.00 & 11 \\
\hline$\Psi$ Observer Bogs + Conifer + Red Squirrel & 77.57 & -1328 & 0.00 & 12 \\
\hline$\Psi$ Observer $\sim$ Bogs + Rivers + Conifer + Red Squirrel & 78.76 & -1327.58 & 0.00 & 13 \\
\hline$\Psi$ Observer Bogs + Conifer & 79.37 & -1329.91 & 0.00 & 11 \\
\hline$\Psi$ Observer Bogs + Rivers + Conifer & 80.79 & -1329.61 & 0.00 & 12 \\
\hline$\Psi$ Observer Bogs + Conifer Scrub & 81.58 & -1331.01 & 0.00 & 11 \\
\hline$\Psi$ Observer Bogs + Rivers + Conifer Scrub & 83.27 & -1330.85 & 0.00 & 12 \\
\hline$\Psi$ Observer Streams + Conifer Scrub & 84.00 & -1332.23 & 0.00 & 11 \\
\hline$\Psi$ Observer NULL & 119.73 & -1352.11 & 0.00 & 9 \\
\hline$\Psi$ Observer $\sim$ Year & 121.46 & -1351.96 & 0.00 & 10 \\
\hline
\end{tabular}

${ }^{\mathrm{a}} \mathrm{AIC}_{\mathrm{c}}$ of best model $=2602.58$

\section{Results}

Observers identified rusty blackbirds at 209 of the 1960 points visited over two years (105 points in 2016, 104 points in 2017), a naïve occupancy rate of 10.7\%. At 174 sites we detected only one individual, whereas at 30 sites we observed 2 individuals, and at 5 sites we observed 3 individuals. The factor that most strongly affected detectability was observer (Table 2), whereas the model including cloud cover was marginally better than the null model but performed considerably worse than the model only including observer $(\triangle \mathrm{AICC}=3.11, \mathrm{wi}=0.14)$. The model including precipitation performed similarly to the null model $(\triangle \mathrm{AICc}=4.53$, wi $=0.07$; Table 2$)$. A post-hoc check of an observer + cloud model revealed that adding cloud cover improved model fit only slightly (AICC $=2721.15$ ). Models including wind, time of day, and ordinal day were all worse than the null model, and a post-hoc assessment of the model containing time of day and observer did not prove to be important in detection probability. Based on these findings, we included observer in the base model for all subsequent occupancy models.

Four models were included in our $95 \%$ confidence set of best occupancy models, and of these the model that best predicted rusty blackbird occupancy contained lakes and ponds $(\beta=7.21 \pm 0.94)$, bogs $(\beta=3.53 \pm 0.73)$, streams $(\beta=2.06 \pm 0.41)$, and rivers $(\beta=6.94 \pm 3.57)$ (Table 3$)$. This model included strong positive relationships for lakes and ponds, bogs, and streams, and a weaker positive relationship for rivers (Figure 2a-d). Based on this model, the mean predicted occupancy of rusty blackbirds across our study area was $12.2 \%(95 \%$ confidence interval $=9.4-15.7 \%$; Figure 3$)$. The next two models in the best model set were similar to the best model, but with rivers being replaced by either conifer scrub $(\beta=-0.38 \pm 0.44)$, or conifer forest $(\beta=0.14 \pm 0.36)$; no strong directional relationship was observed between the probability of rusty blackbird occurrence and conifer scrub cover or conifer forest (Table 3; Figure 2e-f). The final model in our best model set was the global model. Red squirrels were more abundant in the summer of 2016 compared with the summer of 2017 (i.e., they were more abundant following a high cone production year), with $84 \%$ of squirrels detected in 2016 [37]. While red squirrel presence did not appear in our $95 \%$ confidence set of best occupancy models, adding red squirrel to the best-fit model improved it slightly (AIC $=2601.99 ;(\beta=-0.49$ 
\pm 0.33 ). Additionally, a red squirrel by year interaction term was added to the best model post hoc; inclusion of this interaction term among the best models was not supported (AICc $=2605.17$ ). We followed the same process with an interaction term that included red squirrel and elevation, and found that this interaction term also did not improve our best model (AICc $=2604.16$ ). We found no evidence that squirrels meaningfully influenced rusty blackbird distribution or occupancy (Table 3; Figure $2 \mathrm{~g}$ ).
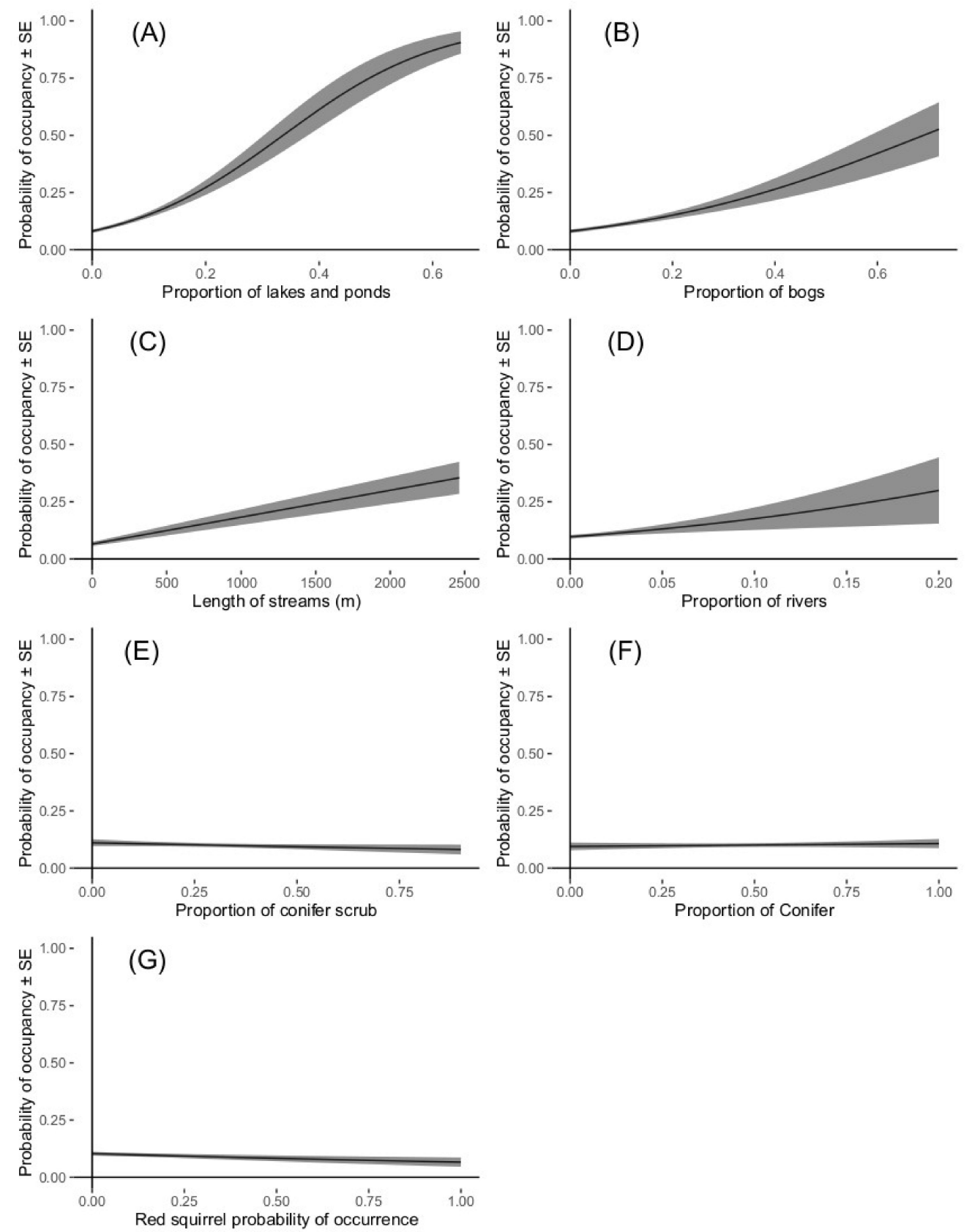

Figure 2. Relationship between rusty blackbird probability of occurrence and landcover variables found in our highest-ranked occupancy models (A-F), as well as with red squirrel occurrence (G), in Newfoundland, Canada, in 2016 and 2017 ( $n=1960)$. Landcover variables were (A) proportion of lakes and ponds (B) proportion of bogs (C) length of stream (D) proportion of rivers, (E) proportion of conifer scrub, (F) proportion of conifer forest, and (G) red squirrel probability of occurrence. Each variable was plotted using the best model that included that factor (Table 3). Error bars show one standard error. Note that while the vertical axis is the same for all plots, the scale and units of the horizontal axis varies. 


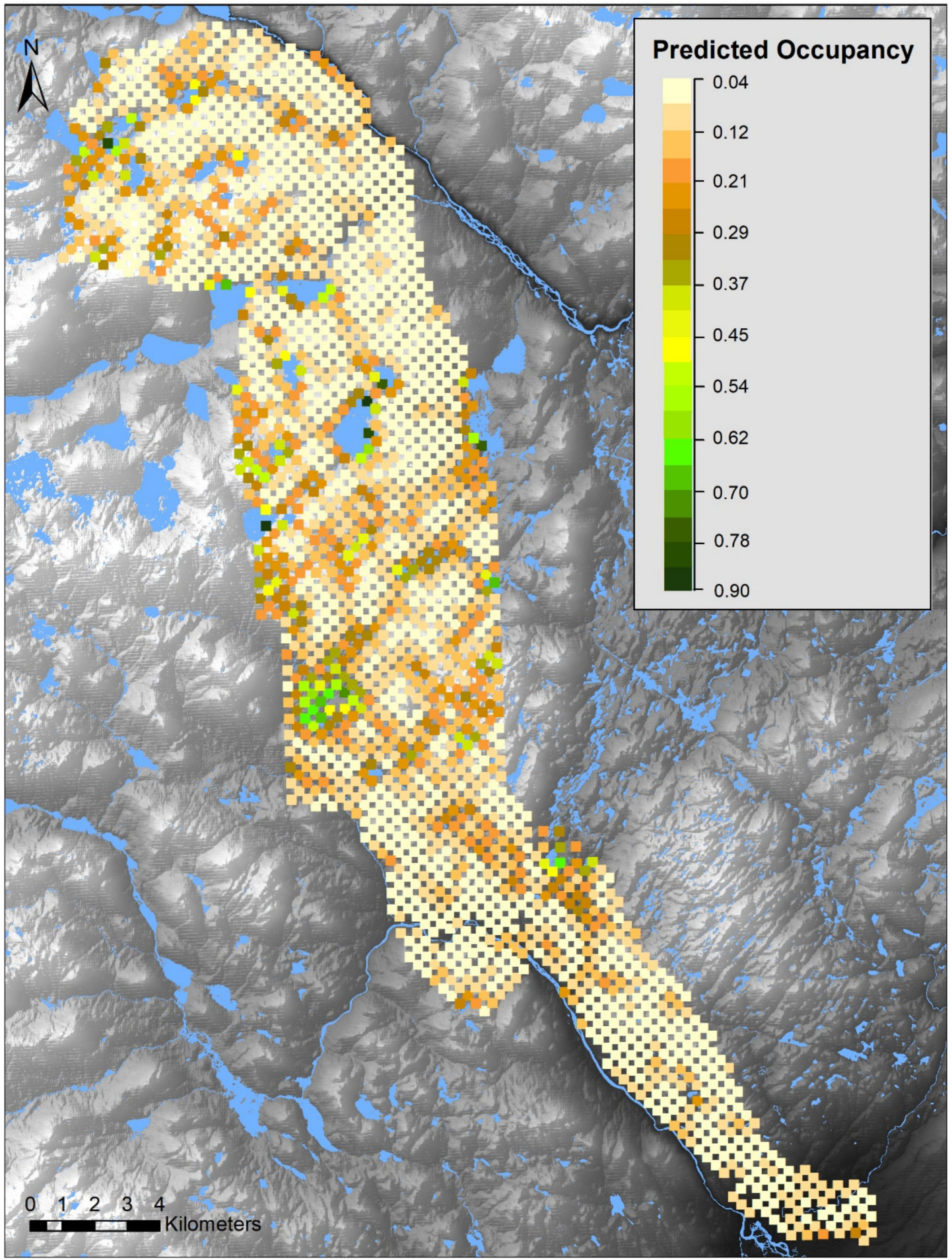

Figure 3. Probability of rusty blackbird occupancy mapped across our study area in Newfoundland, Canada, in 2016 and 2017. Probability of occupancy was estimated from our best model (Table 3) based on landcover data available in the provincial forest resource inventory and publicly available national CanVec stream data.

\section{Discussion}

Of our 31 a priori models, we found that the amount of lakes and ponds, streams, bogs, and rivers best predicted rusty blackbird occurrence. Aquatic invertebrates are an important food source for rusty blackbirds [22,23], and blackbird foraging activities often focus on the edges of waterbodies 
with abundant shallow water [2]. Thus, the importance of these aquatic habitats in our model is not surprising and is consistent with findings from previous studies of rusty blackbird habitat occupancy [22-24]. However, the absence of conifer forest from our best model and the apparent overall weak influence of either conifer forest or conifer scrub cover on rusty blackbird occupancy initially appears counterintuitive. Powell et al. [24] suggested that blackbird habitat occupancy in Maine, where the forest has a greater component of deciduous cover, is heavily influenced by the presence of patches of suitable conifer habitat in which to nest. In contrast, our study area on Newfoundland is dominated by dense, often single species, conifer stands and consequently rusty blackbirds may not need to actively select for such a ubiquitous feature on the landscape. In particular, wet soils in riparian zones and wetlands on Newfoundland often support dense stands of conifer scrub. To retain landcover features where rusty blackbirds were most likely to occur, we only included forest types that were dominated by either black spruce or balsam fir. Since primarily deciduous stands dominated less than $5 \%$ of points, most forested points included conifer cover. Thus, within the spatial scale at which we examined occupancy, rusty blackbirds in Newfoundland appear to select sites primarily based on the availability of appropriate foraging habitat. Additional research such as radio-telemetry studies or nest searching may allow us to better describe the nesting habitat needs of rusty blackbirds in Newfoundland, as well as their space use and breeding ecology. We did not find a strong influence of red squirrel occurrence or year on rusty blackbird occupancy. This is unexpected, given the notable difference in red squirrel detections between years [37]. Red squirrels are known to reproduce later in the season following low cone crop years so that they can take better advantage of seasonal food resources [60], and this influences juvenile survivorship when compared with individuals born earlier in the year [61]. Luepold et al. [22] found that during a year when red squirrel occurrence was higher following a large mast crop, red squirrels were more frequently observed to prey on rusty blackbird nests. It is possible that red squirrels are preying upon rusty blackbird nests, but that despite this, the blackbirds continue to return to habitat where red squirrels are present due to other attractive factors. Red squirrels are prominent members of most boreal forest ecosystems and can directly affect other species through an omnivorous diet and generalist predatory behavior [62,63]. De Santo and Willson [64] found that nest predation was lowest in open wetlands and within forests, compared with both forest and wetland edges and clearcuts. Our observation that red squirrel presence was not strongly related to rusty blackbird occupancy-despite marginally improving our best model in a post-hoc test-may suggest a deviation from the typical vulnerability to nest predation commonly experienced by forest songbirds $[63,65,66]$. Related research at our study site indicates that squirrels are much more abundant at lower elevations [37] and in these areas they may have caused the local extirpation of breeding populations of another species, the gray-cheeked thrush (McDermott, unpublished data; see also [36,44]). Unlike gray-cheeked thrushes, we found that elevation appeared to have little or no effect on rusty blackbird occupancy. It may be that the impact of squirrels is not as strong for rusty blackbirds as for gray-cheeked thrushes because of a greater capacity to deter predators; for example, rusty blackbirds have been observed mobbing presumed threats (e.g., field crews) near nest sites [53], a trait which is known to drive nest predators away [67]. Alternatively, there may be aspects of their nest site selection that enable them to avoid strong impacts of squirrel predation. Aquatic habitat may also impede squirrel movements during summer and consequently compel squirrels and blackbirds to select different habitats.

McDermott et al. [37] found that squirrel occurrence was inversely related to surface water and ambiguously related to "open" habitats (an amalgamation of bogs, barrens, and other natural openings), which could offer some protection to rusty blackbird nests near those habitat types. Specifically, these open, wet habitats could act as barriers to red squirrel movement. However, the weak relationship between rusty blackbirds and red squirrels could also have resulted from an ecological trap (see Powell et al. [21]), as Luepold et al. [22] found red squirrels to be the most important predator of rusty blackbird nests in New England. More research into rusty blackbird nest success and predator 
dynamics on Newfoundland may help to clarify the impact of the introduction of red squirrels on this and other boreal bird species.

Consistent with the findings of Powell et al. [24], clearcuts did not appear in our best model set, indicating that this habitat type had little influence on blackbird occupancy. Provincial forestry regulations require that an unharvested buffer strip at least 20-m wide be left along the shorelines of water bodies, and Whitaker and Montevecchi [68] found that, in western Newfoundland, abundance of rusty blackbirds did not differ between these buffer strips and unharvested shorelines. Thus, it may be that current forestry regulations are sufficient to safeguard blackbird habitat needs on Newfoundland. However, because it has been suggested that harvested forests can act as ecological traps for Rusty Blackbirds [21], more research into nesting success of blackbirds at this site could provide a more nuanced perspective into effects of forest management. In addition, the influence of forest management history and temporal patterns at this site is as yet unexplored. This study area provides a unique opportunity to study rusty blackbirds with an abundance of old growth forest. Given that Newfoundland remains a stronghold for rusty blackbirds, it may be worth investigating in more detail the relationship between forest characteristics (i.e., age, structure, diversity) and rusty blackbird abundance.

Our best detectability model included observer as an explanatory variable. Contrary to Powell et al. [24], wind, precipitation, cloud cover, time of day, and ordinal day did not strongly affect detectability, which may reflect differences in the sampling protocol. Variability in detection probability by the observer may reflect false negatives (species was present but was not detected) or false positives (an observer incorrectly identified a species as present; [69-71]). However, false positives are unlikely because similar-looking species (e.g., other blackbirds) are not present on Newfoundland. Intuitively, the frequency of these errors is lower if observers have higher skill levels [70]; all of our observers were skilled in the identification of local species prior to data collection. Given the naïve and predicted blackbird occupancy rates of only $10.7 \%$ and $12.2 \%$, respectively, across the study area, differences in detectability between observers may at least in part reflect the potential for some observers to have been assigned survey areas where they were less likely to encounter rusty blackbirds (e.g., due to physical ability or back-country navigation skills). Broadcasting rusty blackbird calls would likely increase detections among all observers because of behavioural responses to conspecific bird calls [24]. In addition, ensuring that all surveyors are of a similar skill level in fitness and backcountry orienteering would improve the consistency of detection rates between observers, since it would ensure that observers cover a similar number of points across a challenging landscape.

The spatial scale at which habitat use is assessed inevitably affects the apparent habitat requirements of a given species [72]; thus, more research on the spatial ecology of rusty blackbirds may lead to improved inferences. Our habitat analysis buffer size reflected the best available home range estimate for rusty blackbirds, although values ranged from 3.8 ha to 172.8 ha [20]. Powell et al. [20] noted that the home range size of colonial rusty blackbirds was significantly larger than that of non-colonial pairs. This likely reflects the potential for birds nesting in loose colonies to share information on the location of short-lived sources of emergent insects, whereas pairs on their own may have more limited sources of food [20]. Therefore, home range size, and a bird's ability to take advantage of available resources may vary drastically based on behavioral factors between individuals. Because we only detected more than two individuals at five out of 209 occupied sites (2.4\%) over the two years, it is likely that, as is typical for much of their breeding range, solitary nesting is prevalent at our study area. Concrete evidence of pair versus colonial status is another area where radio-telemetry studies may improve our understanding of rusty blackbird breeding ecology.

Our study is among the first of its kind to model rusty blackbird occupancy using information on habitat from a typical Forest Resource Inventory database that was developed based on high resolution aerial photography, as well as from other publicly available landcover data (e.g., our stream data; but, see Wohner et al. [27]). The fact that we did not undertake field habitat surveys allowed us to efficiently complete a systematic survey of over 1900 point counts across a large area having 
limited road access. Remote sensing resources such as aerial imagery are considered valuable tools in predicting species distributions and developing population estimates [73,74]. Further, this is the same spatial database that the province uses to plan and monitor industrial forestry and other forms of natural resource management. Consequently, it would be straightforward to use the findings of studies such as this, which are based on information contained in those spatial databases, to predict and map the distribution of rusty blackbirds across the landscape (e.g., Figure 3). This offers the opportunity to easily incorporate consideration of blackbird habitat into conservation, management, and research planning. For example, while the mean predicted occupancy across our study area was $12.2 \%$, the $5 \%$ of points having the highest estimates had a mean predicted occupancy of $46.8 \%$ (range $32.9 \%-86.9 \%$ ); this type of information could be of value in planning research or rapidly identifying high-value habitat during land use planning. Similar forest resource databases are available for many jurisdictions across the North American boreal forest, especially those subject to large scale extractive resource use, so this approach may be applied across much of the species' breeding range to map and protect potential blackbird habitat. Based on our findings, and the findings from other studies on Rusty Blackbird occupancy and habitat use (e.g., [21,22,24,26,27]), key Rusty Blackbird habitat with a high probability of occupancy—such as concentrations of wetlands, waterbodies and watercourses, with nearby dense conifer forest-may be identified from remotely sensed data. Once these areas are identified, prioritization of survey areas and conservation planning may proceed.

\section{Conclusions}

This is the first quantitative study of rusty blackbirds on the island of Newfoundland, and among the first published studies to use remotely-sensed data to predict their breeding habitat. Given that they may be genetically distinct, this population is important to the overall conservation and recovery of the species. Further, the decline of rusty blackbirds on Newfoundland has been more gradual than in most other areas of the species' breeding range, and they continue to be detected in higher numbers on Newfoundland than elsewhere in their breeding range [7]. Indeed, our naïve occupancy rate was $41.7 \%$ higher than that of Powell et al. [24] for a population in northern New England, while our predicted occupancy in the upper $5 \%$ of most preferred sites averaged more than four times the overall naïve occupancy rate.

Consistent with past research, our study indicates a strong association for breeding rusty blackbirds with aquatic habitats in the boreal forest, including lakes, ponds, streams, rivers, and bogs; these findings echo the results of Bale et al. [46], and the conservation value of these wetland environments, particularly in the face of climate change. Due to the island's cool, wet maritime climate, boreal landscapes across much of Newfoundland consist of a complex mosaic of bogs and surface water intertwined with coniferous scrub and forests. This appears to offer relatively plentiful habitat for rusty blackbirds, and presents an opportunity to study this declining species in a region where relatively high numbers persist.

Author Contributions: Conceptualization, K.K.E.M., L.L.P., J.P.B.M., D.M.W., I.G.W.; methodology, K.K.E.M., L.L.P., J.P.B.M., D.M.W., I.G.W.; formal analysis, K.K.E.M., L.L.P., D.M.W.; investigation, J.P.B.M., K.K.E.M.; resources, I.W., D.M.W.; data curation, K.K.E.M., J.P.B.M.; writing-original draft preparation, K.K.E.M.; writing-review and editing, K.K.E.M., L.L.P., J.P.B.M., D.M.W., I.G.W; visualization, K.K.E.M., L.L.P, J.P.B.M., D.M.W.; supervision, J.P.B.M., I.G.W., D.M.W., L.L.P.; project administration, J.P.B.M., D.M.W., I.G.W.; funding acquisition, I.G.W., D.M.W.; All authors have read and agreed to the published version of the manuscript.

Funding: This research was funded by the Centre for Forest Science and Innovation (Newfoundland and Labrador Department of Natural Resources), the Natural Sciences and Engineering Research Council of Canada, and Gros Morne National Park of Canada. The Article Processing Charges were funded by Parks Canada.

Acknowledgments: Many thanks to field surveyors Elora Grahame, Brendan Kelly, Noah Korne, Anna Rodgers, Meaghan Tearle, and Benjamin West. Matthew Brooks and Andrew Curtis also provided critical field support, while Jake Burton (Parks Canada) offered geomatics assistance and Dylan Harding helped with data curation. The Newfoundland and Labrador Department of Fisheries and Land Resources, Forestry and Wildlife Branch provided use of a cabin for field surveys and other logistical support. Research was conducted under a scientific research permit from the Newfoundland and Labrador Department of Environment and Conservation, Parks and Natural 
Areas Division, as well as a research permit from the Department of Fisheries and Land Resources, Forestry and Wildlife Branch, and animal care approval (16-16-IW) from the Memorial University of Newfoundland Institutional Animal Care Committee.

Conflicts of Interest: The authors declare no conflict of interest. The funders had no role in the design of the study; in the collection, analyses, or interpretation of data; in the writing of the manuscript, or in the decision to publish the results.

\section{References}

1. Committee on the Status of Endangered Wildlife in Canada (COSEWIC). COSEWIC Assessment and Status Report on the Rusty Blackbird Euphagus carolinus in Canada; COSEWIC: Ottawa, ON, Canada, 2017; Available online: https://www.canada.ca/en/environment-climate-change/services/species-risk-publicregistry/cosewic-assessments-status-reports/rusty-blackbird-2017.html (accessed on 7 May 2020).

2. Greenberg, R.; Droege, S. On the decline of the Rusty Blackbird and the use of ornithological literature to document long-term population trends. Conserv. Biol. 1999, 13, 553-559. [CrossRef]

3. Greenberg, R.; Matsuoka, S.M. Rangewide ecology of the declining Rusty Blackbird: Mysteries of a species in decline. Condor 2010, 112, 770-777. [CrossRef]

4. Avery, M.L. Rusty Blackbird (Euphagus carolinus), version 1.0. In Birds of the World; Poole, A.F., Ed.; Cornell Lab of Ornithology: Ithaca, NY, USA, 2020. [CrossRef]

5. Faaborg, J.; Holmes, R.T.; Anders, A.D.; Bildstein, K.L.; Dugger, K.M.; Gauthreaux, S.A.; Heglund, P.; Hobson, K.A.; Jahn, A.E.; Johnson, D.H. Conserving migratory land birds in the new world: Do we know enough? Ecol. Appl. 2010, 20, 398-418. [CrossRef]

6. Marra, P.P.; Cohen, E.B.; Loss, S.R.; Rutter, J.E.; Tonra, C.M. A call for full annual cycle research in animal ecology. Biol. Lett. 2015, 11, 1-4. [CrossRef] [PubMed]

7. Greenberg, R.; Demarest, D.W.; Matsuoka, S.M.; Mettke-Hofmann, C.; Evers, D.; Hamel, P.B.; Luscier, J.; Powell, L.L.; Shaw, D.; Avery, M.L.; et al. Understanding declines in Rusty Blackbirds. In Boreal Birds of North America: A Hemispheric View of Their Conservation Links and Significance; Studies in Avian Biology (no. 41); Wells, J.V., Ed.; University of California Press: Berkeley, CA, USA, 2011; pp. 107-126.

8. Edmonds, S.T.; Evers, D.C.; Cristol, D.A.; Mettke-Hofmann, C.; Powell, L.L.; McGann, A.J.; Armiger, J.W.; Lane, O.P.; Tessler, D.F.; Newell, P.; et al. Geographic and seasonal variation in mercury exposure of the declining Rusty Blackbird. Condor 2010, 112, 789-799. [CrossRef]

9. Hobson, K.A.; Bayne, E.M.; van Wilgenburg, S.L. Large-scale conversion of forest to agriculture in the Boreal Plains of Saskatchewan. Conserv. Biol. 2002, 16, 1530-1541. [CrossRef]

10. Morissette, J.L.; Bayne, E.M.; Kardynal, K.J.; Hobson, K.A. Regional variation in responses of wetland-associated bird communities to conversion of boreal forest to agriculture. Avian Conserv. Ecol. 2019, 14, 12. [CrossRef]

11. McClure, C.J.W.; Rolek, B.W.; McDonald, K.; Hill, G.E. Climate change and the decline of a once common bird. Ecol. Evol. 2012, 2, 370-378. [CrossRef]

12. Stralberg, D.; Matsuoka, S.M.; Hamann, A.; Bayne, E.M.; Solymos, P.; Schmiegelow, F.K.A.; Wang, X.; Cumming, S.G.; Song, S.J. Projecting boreal bird responses to climate change: The signal exceeds the noise. Ecol. Appl. 2015, 25, 1112-1128. [CrossRef]

13. Holmes, R.T.; Marra, P.P.; Sherry, T.W. Habitat specific demography of breeding Black-throated Blue Warblers (Dendroica caerulescens): Implications for population dynamics. J. Anim. Ecol. 1996, 65, 183-195. [CrossRef]

14. Holt, C.A.; Fuller, R.J.; Dolman, P.M. Deer reduce habitat quality for a woodland songbird: Evidence from settlement patterns, demographic parameters, and body condition. Auk 2013, 130, 13-20. [CrossRef]

15. Matsuoka, S.M.; Handel, C.M.; Ruthrauff, D.R. Densities of breeding birds and changes in vegetation in an Alaskan boreal forest following a massive disturbance by spruce beetles. Can. J. Zool. 2001, 79, 1678-1690. [CrossRef]

16. Nappi, A.; Drapeau, P.; Saint-Germain, M.; Angers, V.A. Effect of fire severity on long-term occupancy of burned boreal conifer forests by saproxylic insects and wood-foraging birds. Int. J. Wildland Fire 2009, 19, 500-511. [CrossRef]

17. Hannon, S.J.; Schmiegelow, F.K.A. Corridors may not improve the conservation value of small reserves for most boreal birds. Ecol. Appl. 2002, 12, 891-899. [CrossRef] 
18. Potvin, F.; Bertrand, N. Leaving forest strips in large clearcut landscapes of boreal forest: A management scenario suitable for wildlife? For. Chron. 2004, 80, 44-53. [CrossRef]

19. Ellison, W.G. The Status and Habitat of the Rusty Blackbird in Caledonia and Essex Counties; Vermont Fish and Wildlife Department: Woodstock, VT, USA, 1990.

20. Powell, L.L.; Hodgman, T.P.; Glanz, W.E. Home ranges of Rusty Blackbirds breeding in wetlands: How much would buffers from timber harvest protect habitat? Condor 2010, 112, 834-840. [CrossRef]

21. Powell, L.L.; Hodgman, T.P.; Glanz, W.E.; Osenton, J.D.; Fisher, C.M. Nest-site selection and nest survival of the Rusty Blackbird: Does timber management adjacent to wetlands create ecological traps? Condor 2010, 112, 800-809. [CrossRef]

22. Luepold, S.H.B.; Hodgman, T.P.; McNulty, S.A.; Cohen, J.; Foss, C.R. Habitat selection, nest survival, and nest predators of Rusty Blackbirds in northern New England, USA. Condor 2015, 117, 609-623. [CrossRef]

23. Matsuoka, S.M.; Shaw, D.; Johnson, J.A. Estimating the abundance of nesting Rusty Blackbirds in relation to the wetland habitats in Alaska. Condor 2010, 112, 825-833. [CrossRef]

24. Powell, L.L.; Hodgman, T.P.; Fiske, I.J.; Glanz, W.E. Habitat occupancy of Rusty Blackbirds (Euphagus carolinus) breeding in northern New England, USA. Condor 2014, 116, 122-133. [CrossRef]

25. Matsuoka, S.M.; Shaw, D.; Sinclair, P.H.; Johnson, J.A.; Corcoran, R.M.; Dau, N.C.; Meyers, P.M.; Rojek, N.A. Nesting ecology of the Rusty Blackbird in Alaska and Canada. Condor 2010, 112, 810-824. [CrossRef]

26. Buckley, S.H. Rusty Blackbirds in Northeastern Industrial Forests: A Multi-scale Study of Nest Habitat Selection and Nest Survival. Master's Thesis, SUNY College of Environmental Sciences and Forestry, Syracuse, NY, USA, April 2013.

27. Wohner, P.J.; Foss, C.R.; Cooper, R.J. Rusty Blackbird habitat selection and survivorship during nesting and post-fledging. Diversity 2020, 12, 221. [CrossRef]

28. Morosinotto, C.; Thomson, R.L.; Korpimäki, E. Habitat selection as an antipredator behaviour in a multi-predator landscape: All enemies are not equal. J. Anim. Ecol. 2010, 79, 327-333. [CrossRef] [PubMed]

29. Siepielski, A.M. A possible role for red squirrels in structuring breeding bird communities in lodgepole pine forests. Condor 2006, 108, 232-238. [CrossRef]

30. McFarland, K.P.; Rimmer, C.C.; Frey, S.J.K.; Faccio, S.D.; Collins, B.B. Demography, Ecology and Conservation of Bicknell's Thrush in Vermont, with a Special Focus on the Northeast Highlands; Technical Report 08-03; Vermont Center for Ecostudies: Norwich, VT, USA, 2008; Available online: https://www.researchgate.net/ publication/228412299 (accessed on 7 May 2020).

31. Haché, S.; Bayne, E.M.; Villard, M.-A. Postharvest regeneration, sciurid abundance, and postfledging survival and movements in an Ovenbird population. Condor 2014, 116, 102-112. [CrossRef]

32. Dodds, D. Terrestrial mammals. In Biogeography and Ecology of the Island of Newfoundland; South, R., Ed.; Springer: The Hague, The Netherlands, 1983; pp. 163-206.

33. Lewis, K.P. Processes Underlying Nest Predation by Introduced Red Squirrels (Tamiasciurus hudsonicus) in the Boreal Forest of Newfoundland. Ph.D. Thesis, Memorial University of Newfoundland, St. John's, NL, Canada, May 2004.

34. Whitaker, D. The colonisation of Newfoundland by red squirrels (Tamiasciurus hudsonicus); chronology, environmental effects and future needs. Osprey 2015, 46, 23-29.

35. Committee on the Status of Endangered Wildlife in Canada (COSEWIC). COSEWIC Assessment and Status Report on the Red Crossbill Percna Subspecies Loxia Curvirostra Percna in Canada; COSEWIC: Ottawa, ON, Canada, 2016; Available online: https://www.canada.ca/en/environment-climate-change/services/speciesrisk-public-registry/cosewic-assessments-status-reports/red-crossbill-2016.html (accessed on 7 May 2020).

36. Whitaker, D.M.; Taylor, P.D.; Warkentin, I.G. Gray-cheeked Thrush (Catharus minimus minimus) distribution and habitat use in a montane forest landscape of western Newfoundland, Canada. Avian Conserv. Ecol. 2015, 10, 4. [CrossRef]

37. McDermott, J.P.B.; Whitaker, D.M.; Warkentin, I.G. Constraints on range expansion of introduced red squirrels (Tamiasciurus hudsonicus) in an island ecosystem. Can. J. For. Res. 2020. [CrossRef]

38. Benkman, C.W. On the evolution and ecology of island populations of crossbills. Evolution 1989, 43, 1324-1330. [CrossRef]

39. Robertson, B.A.; Hutto, R.L. Is selectively harvested forest an ecological trap for olive-sided flycatchers? Condor 2007, 109, 109-121. [CrossRef] 
40. Vitz, A.C.; Rodewald, A.D. Behavioral and demographic consequences of access to early-successional habitat in juvenile Ovenbirds (Seiurus aurocapilla): An experimental approach. Auk 2013, 130, 21-29. [CrossRef]

41. Charchuk, C.; Bayne, E.M. Avian community response to understory protection harvesting in the boreal forest of Alberta, Canada. For. Ecol. Manag. 2018, 407, 9-15. [CrossRef]

42. Peters, H.S.; Burleigh, T.D. The Birds of Newfoundland; The Riverside Press: Cambridge, MA, USA, 1951.

43. Montevecchi, W.A.; Tuck, L.M. Newfoundland Birds: Exploitation, Study, Conservation; Nuttall Ornithological Club: Cambridge, MA, USA, 1987; ISBN 9997639995.

44. FitzGerald, A.M.; Whitaker, D.M.; Ralston, J.; Kirchman, J.J.; Warkentin, I.G. Taxonomy and distribution of the imperilled Newfoundland Gray-cheeked Thrush, Catharus minimus minimus. Avian Conserv. Ecol. 2017, 12, 10. [CrossRef]

45. Burleigh, T.D.; Peters, H.S. Geographic variation in Newfoundland birds. Proc. Biol. Soc. Wash. 1948, 61, 111-124.

46. Bale, S.; Beazley, K.F.; Westwood, A.; Bush, P. The benefits of using topographic features to predict climate-resilient habitat for migratory forest landbirds: An example for the Rusty Blackbird, Olive-sided Flycatcher, and Canada Warbler. Condor 2020, 122, 1-19. [CrossRef]

47. Thompson, I.D.; Larson, D.J.; Montevecchi, W.A. Characterization of old "wet boreal" forests, with an example from balsam fir forests of western Newfoundland. Environ. Rev. 2003, 11, S23-S46. [CrossRef]

48. McCarthy, J.W.; Weetman, G. Age and size structure of gap-dynamic, old-growth boreal forest stands in Newfoundland. Silva Fenn. 2006, 40, 209-230. [CrossRef]

49. Viglas, J.N.; Brown, C.D.; Johnstone, J.F. Age and size effects on seed productivity in northern black spruce. Can. J. For. Res. 2013, 43, 534-543. [CrossRef]

50. Arsenault, A.; LeBlanc, R.; Earle, E.; Brooks, D.; Clarke, B.; Lavigne, D.; Royer, L. Unravelling the past to manage Newfoundland's forest for the future. Forest. Chron. 2016, 92, 487-502. [CrossRef]

51. Environment Canada. North American Breeding Bird Survey Instructions and Safety Guidelines. 2017. Available online: https:/www.canada.ca/content/dam/eccc/migration/main/reom-mbs/5ee0adba-a60b-41429add-644f35e5935e/bbs_instructions_formatted_en.pdf (accessed on 22 July 2020).

52. Ralph, C.J.; Sauer, J.R.; Droege, S. Monitoring Bird Populations by Point Count; United States Department of Agriculture: Berkeley, CA, USA, 1997. Available online: https://www.fs.fed.us/psw/publications/documents/ psw_gtr149/psw_gtr149.pdf (accessed on 16 June 2020).

53. Powell, L.L.; Hodgman, T.P.; Glanz, W.E.; Osenton, J.D.; Ellis, D.E. A loose colony of Rusty Blackbirds nesting in Northern Maine. Northeast. Nat. 2010, 17, 639-646. [CrossRef]

54. ESRI. ArcGIS Desktop; (10.5.1); Computer Software; Environmental Systems Research Institute: Redlands, CA, USA, 2017.

55. Dormann, C.F.; Elith, J.; Bacher, S.; Buchmann, C.; Carré, G.C.G.; Garcia Márquez, J.R.; Gruber, B.; Lafourcade, B.; Leitao, P.J.; Münkemüller, T.; et al. Collinearity: A review of methods to deal with it and a simulation study evaluating their performance. Ecography 2013, 36, 27-46. [CrossRef]

56. Fiske, I.; Chandler, R. Unmarked: An R package for fitting hierarchical models of wildlife cccurrence and abundance. J. Stat. Softw. 2011, 43, 1-23. [CrossRef]

57. R Core Team. R: A Language and Environment for Statistical Computing, version 3.5.1; R Foundation for Statistical Computing: Vienna, Austria, 2013.

58. Mackenzie, D.I.; Nichols, J.D.; Lachman, G.B.; Droege, S.; Royle, J.A.; Langtimm, C.A. Estimating site occupancy rates when detection probabilities are less than one. Ecology 2002, 83, 2248-2255. [CrossRef]

59. Burnham, K.P.; Anderson, D.R. Model Selection and Multimodel Inference, 2nd ed.; Springer: New York, NY, USA, 2002.

60. Fletcher, Q.E.; Landry-Cuerrier, M.; Boutin, S.; McAdam, A.G.; Speakman, J.R.; Humphries, M.M. Reproductive timing and reliance on hoarded capital resources by lactating red squirrels. Oecologia 2013, 173, 1203-1215. [CrossRef] [PubMed]

61. Williams, C.T.; Lane, J.E.; Humphries, M.M.; McAdam, A.G.; Boutin, S. Reproductive phenology of a food-hoarding mast-seed consumer: Resource- and density-dependent benefits of early breeding in red squirrels. Oecologia 2013, 174, 777-788. [CrossRef]

62. Martin, T.E. Processes organizing open-nesting bird assemblages: Competition or nest predation? Evol. Ecol. 1988, 2, 37-50. [CrossRef] 
63. Bayne, E.M.; Hobson, K.A. Effects of red squirrel (Tamiasciurus hudsonicus) removal on survival of artificial songbird nests in boreal forest fragments. Am. Midl. Nat. 2002, 147, 72-79. [CrossRef]

64. DeSanto, T.L.; Willson, M.F. Predator abundances and predation of artificial nests in natural and anthropogenic coniferous forest edges in southeast Alaska. J. Field Ornithol. 2001, 72, 136-149. [CrossRef]

65. Willson, M.F.; de Santo, T.L.; Sieving, K.E. Red squirrels and predation risk to bird nests in northern forests. Can. J. Zool. 2003, 81, 1202-1208. [CrossRef]

66. Sherry, T.W.; Wilson, S.; Hunter, S.; Holmes, R.T. Impacts of nest predators and weather on reproductive success and population limitation in a long-distance migratory songbird. J. Avian Biol. 2015, 46, 559-569. [CrossRef]

67. Krama, T.; Bērzinšs, A.; Rytkönen, S.; Rantala, M.J.; Wheatcroft, D.; Krams, I. Linking anti-predator behaviour and habitat quality: Group effect in nest defence of a passerine bird. Acta Ethol. 2012, 15, 127-134. [CrossRef]

68. Whitaker, D.M.; Montevecchi, W.A. Breeding bird assemblages inhabiting riparian buffer strips in Newfoundland, Canada. J. Wildl. Manag. 1999, 63, 167-179. [CrossRef]

69. Bart, J. Causes of recording errors in singing bird surveys. Wilson Bull. 1985, 97, 161-172.

70. Farmer, R.G.; Leonard, M.L.; Horn, A.G. Observer effects and avian-call-count survey quality: Rare-species biases overconfidence. Auk 2012, 129, 76-86. [CrossRef]

71. Royle, J.A.; Link, W.A. Generalized site occupancy models allowing for false positive and false negative errors. Ecology 2006, 87, 835-841. [CrossRef]

72. Weins, J.A.; Rotenberry, J.T.; van Horne, B. Habitat occupancy patterns of North American shrubsteppe birds: The effects of spatial scale. Oikos 1987, 48, 132-147. [CrossRef]

73. Gottschalk, T.K.; Huettmann, F.; Ehlers, M. Thirty years of analysing and modelling avian habitat relationships using satellite imagery data: A review. Int. J. Remote Sens. 2007, 26, 2631-2656. [CrossRef]

74. Shealer, D.A.; Alexander, M.J. Use of aerial imagery to assess habitat suitability and predict site occupancy for a declining wetland-dependent bird. Wetl. Ecol. Manag. 2013, 21, 289-296. [CrossRef]

(C) 2020 by the authors. Licensee MDPI, Basel, Switzerland. This article is an open access article distributed under the terms and conditions of the Creative Commons Attribution (CC BY) license (http://creativecommons.org/licenses/by/4.0/). 